\title{
Redox properties of the calcium chelator Fura-2 in mimetic biomembranes
}

\author{
Rubin Gulaboski $^{\mathrm{a}, \mathrm{b}, 1}$, Carlos M. Pereira $^{\mathrm{a}, *}$, M. Natalia D.S. Cordeiro ${ }^{\mathrm{b}}$, \\ A. Fernando Silva ${ }^{a}$, Markus Hoth ${ }^{\mathrm{c}}$, Ivan Bogeski ${ }^{\mathrm{c}, *}$ \\ ${ }^{a}$ CIQ-UP LA, Faculdade de Ciências, Universidade do Porto, Rua do Campo Alegre 687, 4169-007 Porto, Portugal \\ ${ }^{\mathrm{b}}$ REQUIMTE, Faculdade de Ciências, Universidade do Porto, Rua do Campo Alegre 687, 4169-007 Porto, Portugal \\ ${ }^{\mathrm{c}}$ Department of Biophysics, Medical Faculty, Saarland University, Homburg, Germany \\ Received 8 June 2007; received in revised form 26 September 2007; accepted 3 October 2007 \\ Available online 14 November 2007
}

\begin{abstract}
Fura-2 is one of the most commonly used fluorescent dyes to analyze the cytosolic $\mathrm{Ca}^{2+}$ concentration $\left(\left[\mathrm{Ca}^{2+}\right]_{i}\right)$ of living cells. Fura-2dependent measurements of $\left[\mathrm{Ca}^{2+}\right]_{i}$ are susceptible to changes of $\mathrm{pH}$, reactive oxygen species concentration and membrane potential. Fura- 2 is often loaded over the lipophilic cell membrane into the cytosol of a cell in its esterified form (Fura-2/AM) which is then cleaved by endogenous esterases. We have analyzed the electrochemical properties of Fura-2/AM and Fura-2 salt by cyclic voltammetry ("three-phase" and "thin-film" electrode methods). Using Fura-2/AM as a redox facilitator, we were able to mimic the transport of various ions across a lipophilic barrier. We show that Fura-2/AM in this biomimetic set-up can be reversibly oxidized in a single electrochemical step. Its redox reaction was highly proton sensitive in buffers with $\mathrm{pH} \leq 6$. At physiological $\mathrm{pH}$ of around 7.0, the oxidation of Fura-2/AM was coupled to an uptake of mono-anions across the liquid-liquid interface. The voltage-dependence of the redox cycle was sensitive to the free $\mathrm{Ca}^{2+}$ concentration, either after de-esterification of Fura-2/AM, or when Fura- 2 salt was used. The complex between Fura- 2 and $\mathrm{Ca}^{2+}$ ions is ionic (complexation occurs via the dissociated negative groups of Fura forms), while the redox transformations in Fura- 2 occurs at the nitrogen atoms of the amino groups. Our results suggest that redox transformations of the Fura- 2 forms do not affect the binding ability toward Ca ${ }^{2+}$ ions and thus do not interfere with $\left[\mathrm{Ca}^{2+}\right]_{i}$ measurements.
\end{abstract}

(C) 2007 Elsevier Ltd. All rights reserved.

Keywords: Fura-2; Calcium ion transfer; Reactive oxygen species; Mimetic biomembranes; Three-phase electrode; Thin-film electrode; Liquid-liquid interface; Cyclic voltammetry

\section{Introduction}

$\mathrm{Ca}^{2+}$ has very important roles in the regulation of many vital biological processes like the immune response, cell growth, differentiation, exocytosis, muscle contraction, or gene transcription [1,2]. An increase in the intracellular $\mathrm{Ca}^{2+}$ concentration is a key signal in many signalling cascades [3]. One of the key features in the field of $\mathrm{Ca}^{2+}$ signalling is

\footnotetext{
* Corresponding authors.

E-mail addresses: cmpereir@fc.up.pt (C.M. Pereira), ivan.bogeski@uks.eu (I. Bogeski).

${ }^{1}$ On leave from the Department of Chemistry, Faculty of Natural Sciences and Mathematics, Skopje, Macedonia; Faculty for Management of Environment, FON University, Skopje, Macedonia.
}

the precise determination of the intracellular (cytosolic) $\mathrm{Ca}^{2+}$ concentration $\left(\left[\mathrm{Ca}^{2+}\right]_{i}\right)$.

The most popular tools to measure $\left[\mathrm{Ca}^{2+}\right]_{i}$ are the fluorescent $\mathrm{Ca}^{2+}$ indicators and the introduction of Fura- 2 has been a major advance in the field of $\mathrm{Ca}^{2+}$ research [4]. Fura2 (Scheme 1) is a fluorescent, ratiometric indicator of $\mathrm{Ca}^{2+}$, which forms a stable complex with $\mathrm{Ca}^{2+}\left(K_{\mathrm{d}}\right.$ of $0.14 \mu \mathrm{M}$, at $\mathrm{pH}$ of 7.2 and temperature of $22^{\circ} \mathrm{C}$ ). It is commercially available in its ester (Fura-2/AM) and salt (Fura-2 salt) form. The big advantage of the ester form is that it is membrane permeable and can be easily loaded into cells. Once inside the cell, Fura-2/AM (this form cannot bind $\mathrm{Ca}^{2+}$ ) will be de-esterified by the intracellular esterases trapping it in the cells and allowing the binding of $\mathrm{Ca}^{2+}$ by Fura-2. In its 


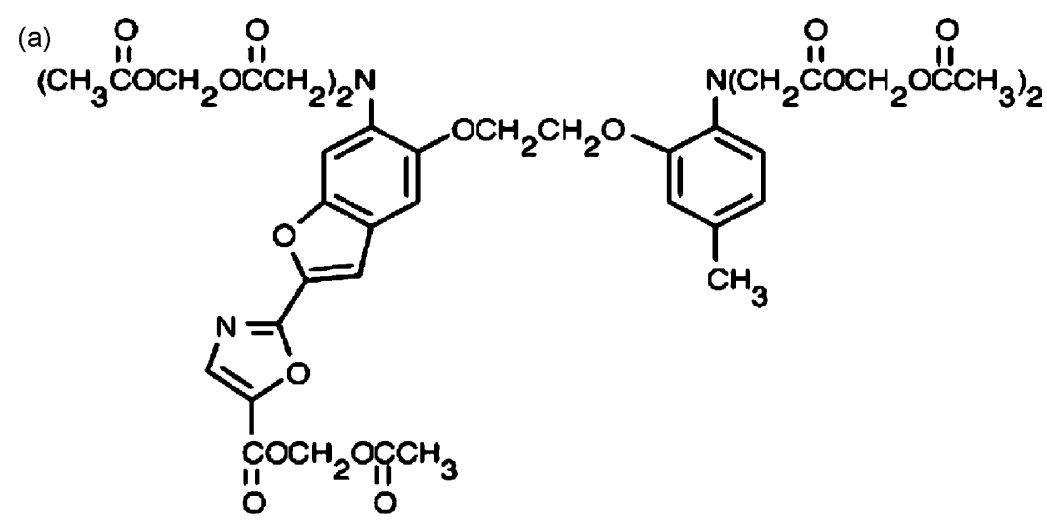

(b)

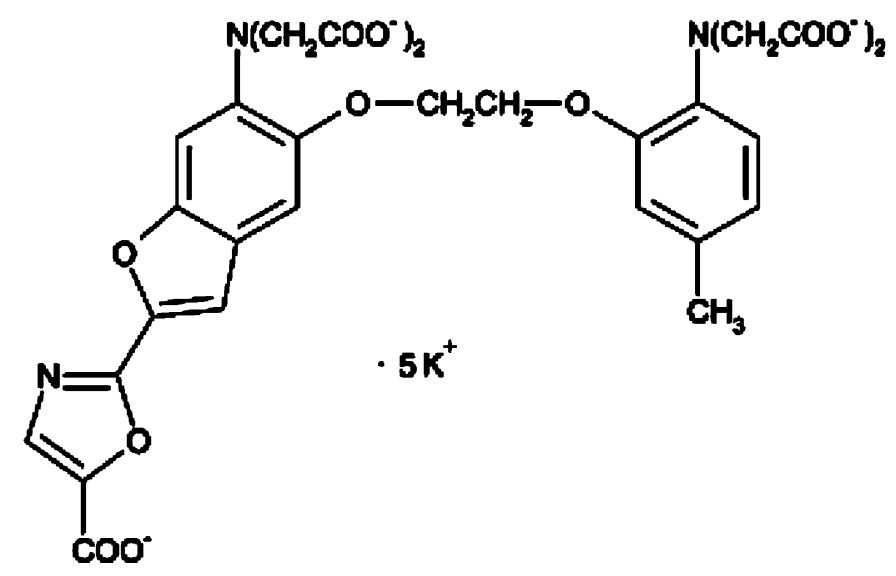

Scheme 1. (a) Structure of Fura-2/AM and (b) structure of Fura-2 potassium salt.

salt form, Fura-2 is scarcely membrane-permeable. Although Fura-2/AM is commonly used and is one of the most reliable $\mathrm{Ca}^{2+}$ indicators, its electrochemical features are still not fully known.

During the last 10 years, there has been an increasing number of studies describing the role of the reactive oxygen species (ROS), $\left(\mathrm{H}_{2} \mathrm{O}_{2}, \mathrm{OH}^{-}, \mathrm{O}_{2}^{-}\right)$in various signalling cascades [5]. Some of them implicate a co-regulation between ROS and $\mathrm{Ca}^{2+}$ metabolism [6,7]. ROS can be produced intracellularly as a result of different signalling cascades including the activation of plasma membrane bound receptors, store operated $\mathrm{Ca}^{2+}$ influx or UV light exposure $[5,6,8]$. Since Fura- 2 is used to analyse $\mathrm{Ca}^{2+}$ concentrations in the cytosol, cytosolic ROS could interact with Fura- 2 and change its $\mathrm{Ca}^{2+}$-binding properties. In addition, there are many other signalling processes in cells, which require constant movement (exchange) of electrons and protons, i.e. reduction, oxidation, deprotonation and protonation. Considering the importance of redox reactions for cell function, it is important to analyze the redox behaviour of Fura-2.

An important parameter for redox reactions is the membrane potential of the cell. In case Fura- 2 based $\mathrm{Ca}^{2+}$ measurements are combined with the patch-clamp technique, the membrane potential of the cell is controlled by the patch amplifier and is often changed between -100 and $+100 \mathrm{mV}$ to study ion channels and signalling mechanisms. In case Fura-2 based $\mathrm{Ca}^{2+}$ measurements are not combined with the patch-clamp technique, the cell usually has a membrane potential between -90 and $+30 \mathrm{mV}$ depending on the stimulus-dependent opening and closing of ion channels. In both cases, changes in membrane potential may affect the redox properties of Fura- 2 and potentially also the $\mathrm{Ca}^{2+}$. binding properties. The analysis of the redox properties of Fura-2 is therefore important to avoid possible artefacts during the measurements of $\left[\mathrm{Ca}^{2+}\right]_{i}$.

The "three-phase" and "thin-film" voltammetric techniques used in this study, have become a valuable approach for studying the redox properties of water-insoluble compounds [9-13], as well as the ion transfer reactions across interfaces between two immiscible liquids [9-19]. Both the electron and the ion transfer are usually portrayed in a single voltammetric response [9-11]. From the features of the voltammetric responses recorded in cyclic or square-wave voltammetry, various thermodynamic and kinetic properties of the investigated systems can be estimated [9-11,14-16]. Comprehensive description of the processes taking place at these voltammetric techniques can be found elsewhere [9-13]. Since Fura-2/AM-based methods are the most commonly applied to study $\mathrm{Ca}^{2+}$ signals in living cells, we put more emphasis on the electrochemical characterization of Fura-2/AM before and after its de-esterification. 


\section{Materials and methods}

Fura-2/AM [2-[6-(bis(carboxymethyl)amino)-5-[2-[2(bis(carboxymethyl)amino)-5-methyl-phenoxy]ethoxy] benzofuran-2-yl]-1,3-oxazole-5-carboxylic acid] (99\% purity), butyryl-cholinesterase (from horse serum) $(99 \%$ purity) and Fura-2 potassium salt (99\% purity) were purchased from Fluka and were used as received. All other chemicals were from Sigma-Aldrich and of highest purity. Fura-2/AM was dissolved in nitrophenyloctyl ether (NPOE) at a concentration of $0.5 \mathrm{mmol} / \mathrm{L}$. Besides the redox compound, NPOE contained $0.1 \mathrm{~mol} / \mathrm{L}$ tetrabuthylammonium perchlorate $\left(\mathrm{Bu}_{4} \mathrm{~N}^{+} \mathrm{ClO}_{4}{ }^{-}\right)$as an organic electrolyte, in case thin-film electrode methodology was used. A graphite rod with diameter of $0.30 \mathrm{~cm}$ was used as a working electrode. $\mathrm{An} \mathrm{Ag} / \mathrm{AgCl}$ (saturated $\mathrm{KCl}$ ) electrode was used as a reference and a platinum wire as an auxiliary electrode. NPOE solution of Fura-2/AM or Fura-2 salt $(0.25 \mu \mathrm{L})$ was deposited on the graphite electrode with the help of a micropipette; in the three-phase electrode, only a droplet was attached to the graphite electrode, while at the thin-film electrode scenario, the organic solution (volume of $0.5 \mu \mathrm{L}$ ) spreads spontaneously over the electrode surface forming a stable film. The modified electrode was thereafter immersed into aqueous solutions containing some of the transferable anions (in three-phase electrode mode), or in buffer solutions having different $\mathrm{pH}$, composed of $0.1 \mathrm{~mol} / \mathrm{L}$ $\mathrm{CH}_{3} \mathrm{COOH}$ and $0.1 \mathrm{~mol} / \mathrm{L} \mathrm{CH}_{3} \mathrm{COONa}$ (at the thin-film electrode mode). In cases of more acidic media, $\mathrm{pH}$ was adjusted by adding of $0.05 \mathrm{~mol} / \mathrm{L}$ nitric acid. In case of the thin-film electrode methodology, the aqueous phase contained $0.1 \mathrm{~mol} / \mathrm{L} \mathrm{NaClO}_{4}$ as a supporting electrolyte in addition to the buffer. Presence of a common ion $\left(\mathrm{ClO}_{4}{ }^{-}\right.$in our case) in both (aqueous and organic) phases is required for controlling of the potential difference at the liquid-liquid interface [11-18]. The butyryl-cholinesterase enzyme was dissolved in ethanol and its working concentration in the aqueous phase was $1 \mathrm{mmol} / \mathrm{L}$. Millipore $\mathrm{Q}$ water was used for preparing all aqueous solutions. Cyclic voltammograms were recorded using an EG\&G PAR 273 potentiostat model.

\section{Results}

\subsection{Voltammetric behaviour of Fura-2/AM in $\mathrm{Ca}^{2+}{ }_{-}$free solutions}

Several cyclic voltammograms of the Fura-2/AM dissolved in NPOE are shown in Fig. 1A. The voltammograms were recorded in three-phase electrode set-up with various monovalent anions present in the aqueous phase. In aqueous solutions with a $\mathrm{pH}$ value of 7 , an electrochemically reversible oxidation of Fura-2/AM was observed, accompanied by the charge-compensating uptake of anions from the aqueous phase into the organic (NPOE) phase. The reduction of the electrochemically created (i.e. the oxidized) form
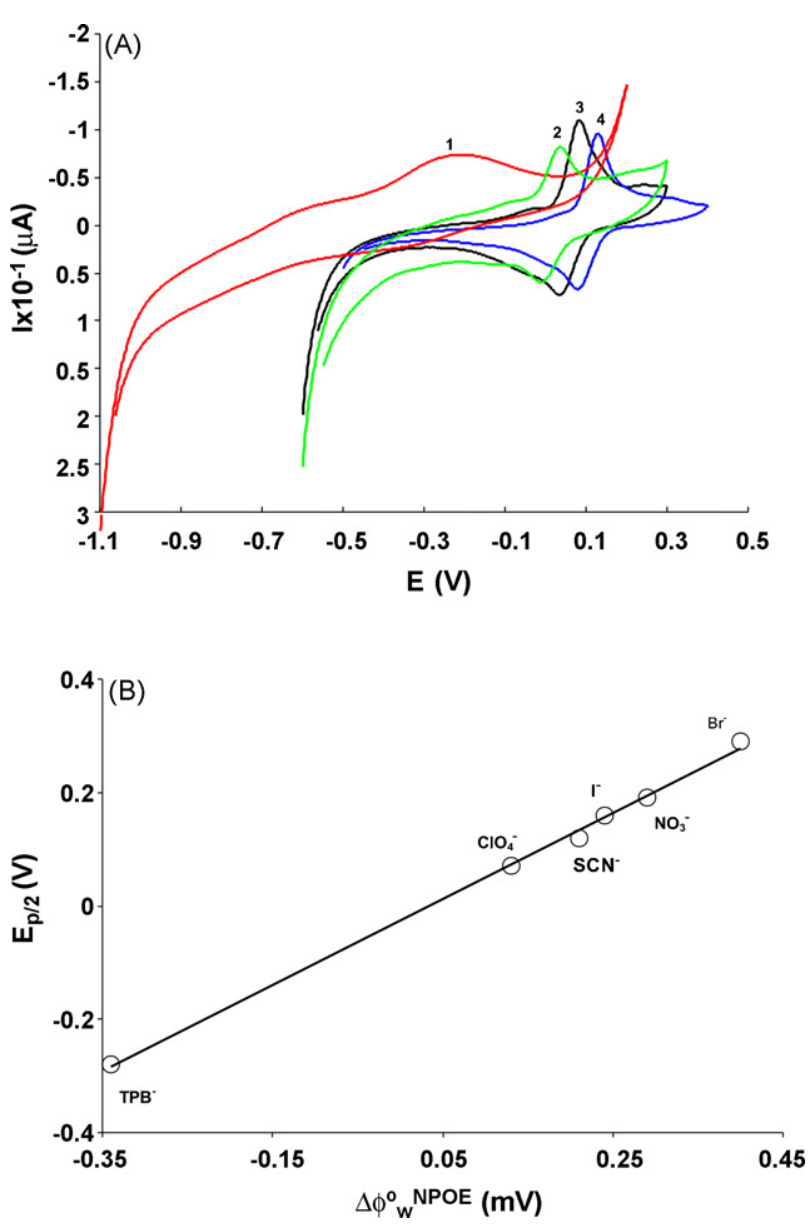

Fig. 1. (A) Cyclic voltammograms of Fura-2/AM recorded in the threephase electrode mode with various monovalent anions present in the aqueous phase having a $\mathrm{pH}$ of 7.0. $c$ (Fura-2/AM $)=0.5 \mathrm{mM}$; scan rate of $10 \mathrm{mV} / \mathrm{s}$; the transferable anions (all present in $0.1 \mathrm{~mol} / \mathrm{L}$ concentration) are: (1) tetraphenylborate (red); (2) $\mathrm{ClO}_{4}^{-}$(green); (3) $\mathrm{SCN}^{-}$(black); (4) $\mathrm{I}^{-}$(blue). (B) Dependence of the measured mid-peak potential of Fura-2/AM cyclic voltammograms on the standard potential of transferable anions across the water-NPOE interface. The values of the standard potential of anion transfer from water to NPOE are taken from references [10,20,21]. 4.7pc(For interpretation of the references to colour in this figure legend, the reader is referred to the web version of the article.)

of Fura-2/AM is being accompanied by the release of these anions into the aqueous solution. Both processes are portrayed in a well-developed pair of anodic and cathodic peaks separated about $60 \mathrm{mV}$ on the potential scale. The potential separation between cathodic and anodic peaks is practically independent on the scan rate, while the peak currents of both peaks increase proportionally with the square root of the scan rate (data not shown). The mid-peak potential of the voltammetric response is a function of the nature of the anions present in the aqueous solution. An increase of the lipophilicity of the transferable anions present in the aqueous phase causes a shift of the mid-peak potentials of Fura-2/AM voltammograms toward more negative potentials (i.e. it is oxidized more easily). Moreover, for a single type of transferable anions present in the aqueous phase, the mid-peak potentials shift for about $60 \mathrm{mV}$ in negative direction per 10- 
fold increase of their concentration in the aqueous phase (data not shown). Fig. 1B depicts the dependence of the mid-peak potentials of the cyclic voltammograms of Fura-2/AM on the standard potentials of transfer from water to NPOE for the different transferable anions, which are initially only present in the aqueous solution (the data for the standard potentials of anion transfers are taken from references [10,20,21]). A linear dependence between these two quantities is observed, with a slope of the linear line of 0.95 . When the aqueous phase has a $\mathrm{pH} \geq 7$ (Fig. 1A), the redox behaviour of the Fura-2/AM (in NPOE) can be described with the following scheme:

Phe-N-R ${ }_{(\mathrm{NPOE})}+\mathrm{An}^{-}{ }_{\text {(water) }}$

$$
\leftrightarrow \text { Phe- } \mathrm{N}^{+}-\mathrm{R}_{(\mathrm{NPOE})}+\mathrm{An}^{-}{ }_{(\mathrm{NPOE})}+1 \mathrm{e}^{-}
$$

where Phe-N-R represents the initial form of Fura-2/AM, and $\mathrm{An}$ is the symbol for the anions present in the aqueous phase. When the thermodynamic conditions are considered, the Nernstian equation evaluated for the reaction (I) has the same form as that previously evaluated by Scholz et al. $[9,10,22]$ :

$$
\begin{aligned}
E= & E_{\mathrm{FURA}^{\theta} \mathrm{FURA}^{+}}+\Delta \varphi^{\theta} \mathrm{An}_{\mathrm{w}}^{\mathrm{NPOE}}-\mathrm{RTF}^{-1} \ln \left[c\left(\mathrm{An}^{-}\right)_{\mathrm{w}}\right] \\
& +\mathrm{RTF}^{-1} \ln \left[c(\mathrm{FURA})_{\mathrm{NPOE}} / 2\right],
\end{aligned}
$$

where $E_{\mathrm{FURA} / \mathrm{FURA}^{+}}^{\theta}$ is the standard redox potential of Fura-2/Am/Fura ${ }^{+}$couple in NPOE, $\Delta \varphi^{\theta} \mathrm{An}_{\mathrm{w}}^{\mathrm{NPOE}}$ is the standard potential of transfer of transferable anions from water to NPOE, $c\left(\mathrm{An}^{-}\right)_{\mathrm{w}}$ the anion concentration in the water phase, while $c(\text { FURA })_{\mathrm{NPOE}}$ is the initial concentration of the Fura-2/AM in NPOE. $R, T$, and $F$ are the gas constant $\left(R=8.314 \mathrm{~J} \mathrm{~mol}^{-1} \mathrm{~K}^{-1}\right)$, thermodynamic temperature $(\mathrm{K})$ and Faraday constant $\left(F=96,500 \mathrm{C} \mathrm{mol}^{-1}\right)$, respectively.

Considering the chemical structure of Fura-2/AM, it is plausible to assume that the amino groups (Phe-N-R) placed at the benzene ring are redox active centres [23-26]. Since both amino groups in the structure of Fura-2/AM are symmetrically positioned, their oxidation will appear at a same potential and will be portrayed in one voltammetric signal. It is worth mentioning that although the chemical environment substituted to both aromatic rings of Fura-2/AM is quite different, this should not significantly affect the electronic density at the redox active amino groups, since the substitutes are far away from the electro-active sites. This is the reason why the redox activity of both amino groups occurs at virtually same potential. The presented voltammetric features of Fura-2/AM imply that this compound can be used as a redox probe in the electrochemically facilitated anion transfer studies across the liquid-liquid interface.

In aqueous solutions with $\mathrm{pH} \leq 6$, a chemically facilitated transfer of protons (accompanied by the chargecompensating uptake of anions) into the organic phase occurs [23-26] and leads to protonation of the N-R groups of the Fura molecules. The voltammetric responses of Fura-2/AM recorded at thin-film electrode mode, in aqueous media hav-
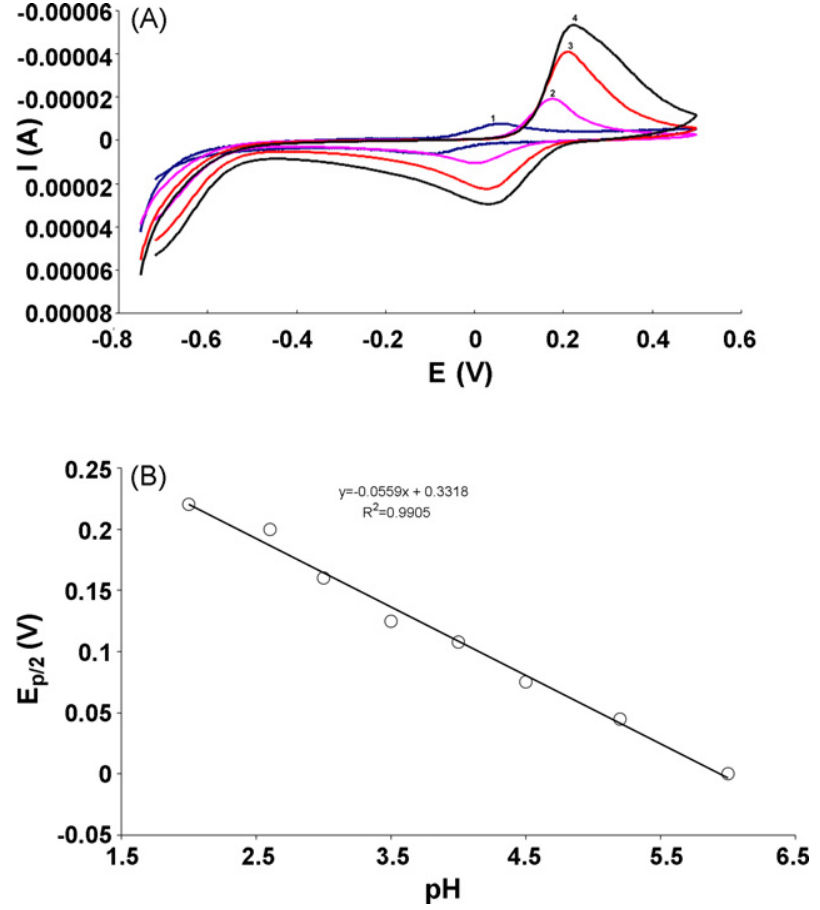

Fig. 2. (A) Cyclic voltammograms of Fura-2/AM recorded in thin-film set-up. In addition to Fura-2/AM, the organic phase contains $0.1 \mathrm{~mol} / \mathrm{L}$ tetrabuthylammonium perchlorate $\left(\mathrm{Bu}_{4} \mathrm{~N}^{+} \mathrm{ClO}_{4}{ }^{-}\right)$. The thin-film electrode is immersed in acetate buffers aqueous solutions having $\mathrm{pH}$ of 6.0 (1), 4.0 (2), 3.0 (3) and 2.6 (4), and containing also $0.1 \mathrm{~mol} / \mathrm{L} \mathrm{NaClO}_{4}$. The scan rate was $30 \mathrm{mV} / \mathrm{s}$. (B) Dependence of the mid-peak potentials of the cyclic voltammograms of Fura-2/AM on the $\mathrm{pH}$ of aqueous phase.

ing $\mathrm{pH}$ from 6 to 2.5 are presented in Fig. 2A. Obviously, the mid-peak potential of recorded cyclic voltammograms is a strong function of $\mathrm{pH}$, being shifted in positive direction by increasing the proton concentration in the aqueous phase. In this case, the oxidation of the protonated Fura-2/AM form is coupled to the transfer of protons between the organic and the aqueous phase. The mid-peak potential of the voltammetric responses shifts by $-56 \mathrm{mV} / \mathrm{pH}$ (Fig. 2B), which means that one $\mathrm{H}^{+}$is being coupled to each N-R group of Fura-2/AM. Moreover, the peak currents rise proportionally to the concentration of the protons in the $\mathrm{pH}$ region from 5.8 to 2.6. This feature is typical for the redox processes of the electrochemical systems that are coupled by preceding chemical reaction $[27,28]$.

Therefore, in aqueous media having $\mathrm{pH} \leq 6$, the redox process of Fura-2/AM at the thin-film electrode set-up can be described with the following reaction scheme:

$$
\begin{gathered}
\text { Phe-N-R }{ }_{(\mathrm{NPOE})}+\mathrm{H}^{+}{ }_{\text {(water) }} \\
\leftrightarrow \text { Phe-NH }{ }^{+}-\mathrm{R}_{(\mathrm{NPOE})} \quad \text { (protonationstep) }
\end{gathered}
$$

$$
\text { Phe-NH }{ }^{+}-\mathrm{R}_{(\mathrm{NPOE})} \leftrightarrow \text { Phe- } \mathrm{N}^{+}-\mathrm{R}_{(\mathrm{NPOE})}+\mathrm{H}^{+}{ }_{(\text {water })}+1 \mathrm{e}^{-}
$$

It is worth noting that all these voltammetric features of Fura-2/AM closely resemble those of the substituted 
tetraalkylphenylenediamines redox liquids, which have been explored in detail by Compton, Marken et al. [23-26]. NPOE itself can also show some electrochemical activity, if the electrolysis is performed at highly negative starting potentials (more negative than $-0.9 \mathrm{~V}$ vs. $\mathrm{Ag} / \mathrm{AgCl}$ ) for certain accumulation times. Therefore, in these kinds of experiments, we avoided potentials more negative than $-0.9 \mathrm{~V}$.

\subsection{Voltammetric behaviour of Fura-2/AM in $\mathrm{Ca}^{2+}$ buffer solutions}

The effect of an increased $\mathrm{Ca}^{2+}$ concentration on the voltammetric response of Fura-2/AM, as recorded in a thinfilm electrode set-up, is shown in Fig. 3A. Obviously, no significant changes in the voltammetric features of Fura2/AM can be observed. Our data is an agreement with the findings that the ester form of Fura-2 (Fura-2/AM) or similar ester forms of $\mathrm{Ca}^{2+}$ indicators do not bind $\mathrm{Ca}^{2+}[29,30]$. In the physiological experiments, the intracellular calcium concentration $\left[\mathrm{Ca}^{2+}\right]_{i}$ is usually evaluated by measuring the fluorescence of the $\mathrm{Ca}^{2+}$-indicating dye Fura-2/AM, which is loaded into the cells. After loading, Fura-2/AM is hydrolyzed to Fura- 2 by intracellular esterases. This dissociated form of Fura- 2 is trapped inside the cell and able to bind the free $\mathrm{Ca}^{2+}$ ions. In Fig. 3B cyclic voltammograms of Fura-2/AM in the presence of butyryl-cholineesterase are shown. These voltammograms were recorded during a gradual increase of the $\mathrm{Ca}^{2+}$ concentration in the aqueous phase. Butyrylcholinesterase is a non-selective, non-specific esterase and capable to catalyse the hydrolysis of various esters. It has been demonstrated that this esterase can also catalyse the hydrolysis of the ester form of Fura-2/AM [31]. In the present scenario, the butyryl-cholinesterase is being partitioned across the interface between the organic phase and aqueous phase, thus being able to break the ester bonds of Fura-2/AM. Analyzing the voltammetric response of Fura2/AM by the thin-film electrode set-up, a thermodynamic shift of the mid-peak potentials by about $60 \mathrm{mV}$ in positive direction per 10-fold increase of the $\mathrm{Ca}^{2+}$ concentration in the water phase was observed (see inset of Fig. 3B). This result is fully consistent with the de-esterified Fura- 2 being capable to form a complex with $\mathrm{Ca}^{2+}$. Experiments performed with Fura-2 salt used as a redox probe instead of Fura-2/AM gave similar results as those of Fura-2/AM obtained in presence of butyryl-cholinesterase (Fig. 3C). These data confirm the hydrolysis of Fura-2/AM to Fura-2, as proposed to explain the voltammograms in Fig. 3B.

\section{Discussion}

During the last few decades, the electrochemical experiments at liquid-liquid interface have revealed insights into signalling processes of biological systems. The new types of interfacial reactions across artificial membranes closely mimic redox processes at living-cell membranes $[9,17,18]$.
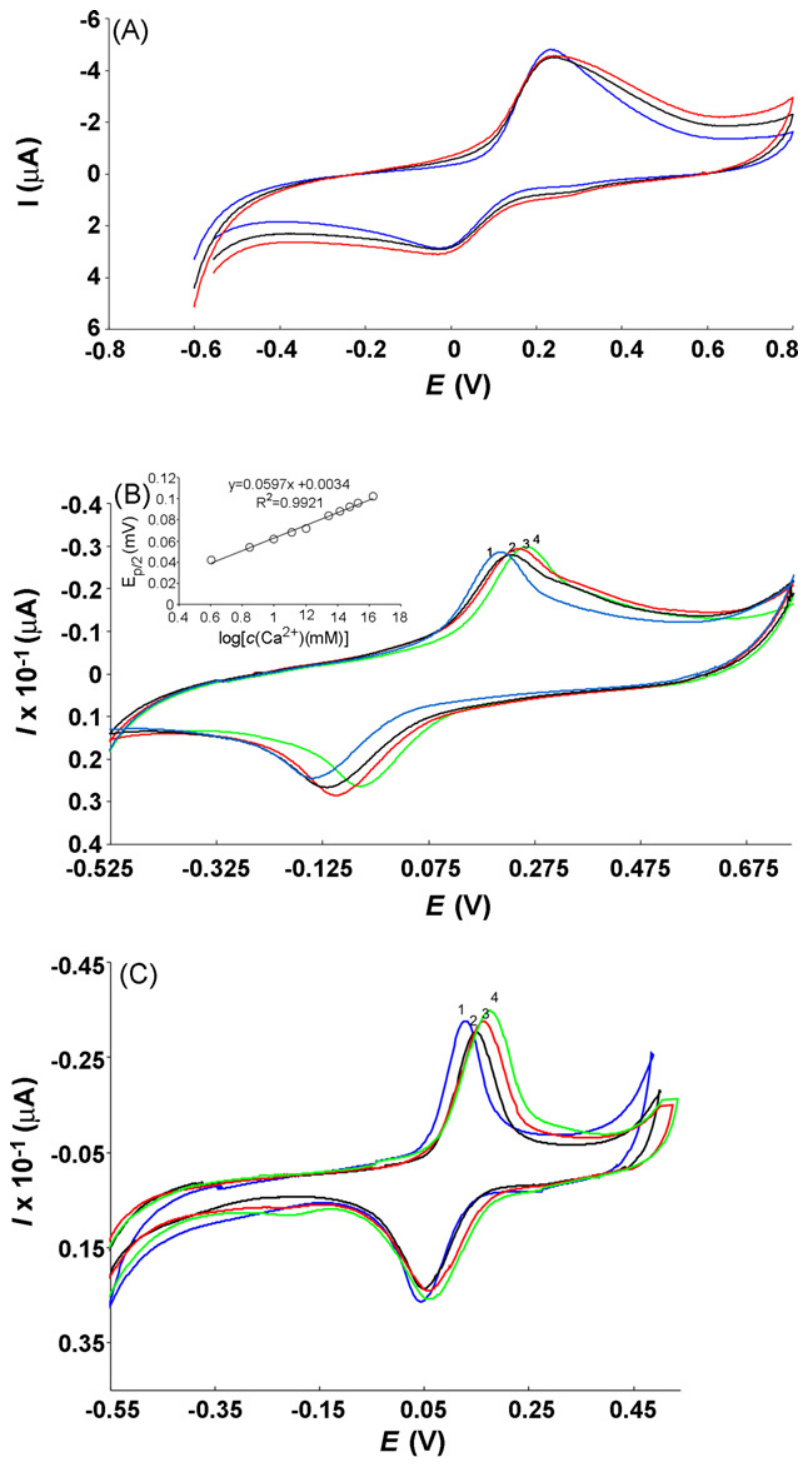

Fig. 3. (A) Effect of the $\mathrm{Ca}^{2+}$ concentration on the cyclic voltammograms (recorded in thin-film set-up) of Fura-2/AM in absence of butyrylcholinesterase. The $\mathrm{pH}$ of the aqueous phase was 6.0 (acetate buffer). $c\left(\mathrm{Ca}^{2+}\right)=30 \mathrm{mM}$ (red); $60 \mathrm{mM}$ (blue) and $90 \mathrm{mM}$ (black). Solution of $\mathrm{Ca}\left(\mathrm{NO}_{3}\right)_{2}$ was used in these experiments; the scan rate was $30 \mathrm{mV} / \mathrm{s}$. (B) Effect of the $\mathrm{Ca}^{2+}$ concentration on the cyclic voltammetric responses of Fura-2/AM recorded in the presence of $1 \mathrm{mM}$ buthyryl-cholinesterase enzyme. $c\left(\mathrm{Ca}^{2+}\right)=4 \mathrm{mM}$ (1), $16 \mathrm{mM}$ (2), $28 \mathrm{mM}$ and (3) $40 \mathrm{mM}$ (4). The inset shows the dependence of the mid-peak potentials of the cyclic voltammograms on the logarithm of the $\mathrm{Ca}^{2+}$ concentration. Other experimental conditions were the same as those in (A). (C) Cyclic voltammograms of Fura-2 salt as a redox probe, the $\mathrm{Ca}^{2+}$ concentrations in the aqueous solutions are the same as those in (B). (For interpretation of the references to colour in this figure legend, the reader is referred to the web version of the article.)

In the present study, we have performed electrochemical experiments using cyclic voltammetry, applied in the threephase and thin-film electrode modes in order to reveal basic electrochemical properties of the $\mathrm{Ca}^{2+}$-indicator Fura-2/AM. We have also analyzed the de-esterification process of Fura$2 / \mathrm{AM}$ in the organic phase, because it closely mimics the 
typical set-up for $\mathrm{Ca}^{2+}$ measurements using imaging technology in living cells.

We have shown that Fura-2/AM can be reversibly oxidized in a single electrochemical step, the electrochemical features of which are highly sensitive to the nature and composition of the aqueous phase. While the redox reaction of this compound is highly proton sensitive in buffers with $\mathrm{pH} \leq 6$, serving as a redox probe for proton transfer across the liquid-liquid interface, in neutral solutions, the oxidation of Fura-2/AM is coupled to an uptake of the mono-anions across the liquid-liquid interface. The ester form of Fura2 (Fura-2/AM) is insensitive to $\mathrm{Ca}^{2+}$. However, after being hydrolyzed with help of an esterase enzyme, it can be converted into a dissociated form capable to bind $\mathrm{Ca}^{2+}$, as evident from the voltammetric outputs (see Fig. 3B). The stoichiometry of the formed complex is $1: 1$ as has been previously reported [4,32]. In principle, it should be possible to calculate the formation constant between Fura and $\mathrm{Ca}^{2+}$ [17], however no attempt has been made to do this since the value of the standard potential of non-assisted ion transfer of $\mathrm{Ca}^{2+}$ is not known.

The experimental set-up used in this study is carefully chosen to mimic the conditions that are used in physiological and biological experiments in living cells. Although the value of the standard Gibbs energy $\left(\Delta G^{\theta}\right)$ of $\mathrm{Ca}^{2+}$ transfer from water to NPOE is not yet determined, it is plausible to assume that it is over $60 \mathrm{~kJ} / \mathrm{mol}$, what is common for other bivalent hydrophilic cations $[17,18]$. Considering this value, we can calculate the partition coefficient of $\mathrm{Ca}^{2+}$ ions $P$ with the following equation: $P=\exp \left[-\Delta G(R T)^{-1}\right]$. The definition of the partition coefficient for a biphasic solute distribution is: $P=c\left(\mathrm{Ca}^{2+}\right)_{\mathrm{O}} / c\left(\mathrm{Ca}^{2+}\right)_{\mathrm{w}}$, (where $c\left(\mathrm{Ca}^{2+}\right)_{\mathrm{O}}$ and $c\left(\mathrm{Ca}^{2+}\right)_{\mathrm{w}}$ are the $\mathrm{Ca}^{2+}$ concentrations in organic phase and water phase, respectively). Therefore, the free partitioned concentration of $\mathrm{Ca}^{2+}$ in the organic phase (NPOE) can be easily calculated and is in the sub-micromolar range. Since this concentration is close to the free intracellular $\mathrm{Ca}^{2+}$ concentration in living cells [33], our experimental set-up mimics the physiologically relevant situation. During the electrochemical experiment, the concentration of $\mathrm{Ca}^{2+}$ ions in the organic phase will increase due to their assisted transfer by the Fura- 2 redox transformation in NPOE. This $\mathrm{Ca}^{2+}$ increase mimics the activation of a cell.

While the redox properties of Fura- 2 can be experimentally influenced by applying a potential difference, by analogy, in the biological systems, the membrane potential of a cell or production of ROS (like peroxide and superoxide radicals) could influence the redox properties of Fura-2 during imaging experiments or patch-clamp experiments. The results presented in this paper suggest that the redox transformations of the Fura- 2 forms do not affect the binding ability toward the $\mathrm{Ca}^{2+}$ ions. Obviously, the complex build between Fura- 2 and $\mathrm{Ca}^{2+}$ ions is ionic, while the redox transformation in the Fura-2 systems takes place at the nitrogen atoms of the amino groups. Therefore, no side effects are expected during $\mathrm{Ca}^{2+}$ measurements with Fura-2 in living cells, regardless of which redox form of Fura- 2 is present in the cell.

\section{Acknowledgements}

R. Gulaboski thanks the Fundação para a Ciência e a Tecnologia (FCT) of Portugal for providing of a postdoctoral fellowship (SFRH/BPD/14894/2004), and C.M. Pereira, acknowledges support from FCT (POCI/QUI/57679/2004). This work was also supported by the Deutsche Forschungsgemeinschaft (SFB 530, project A3 and Graduate College 845 "Molecular, physiological and pharmacological analysis of cellular membrane transport" to M. Hoth) and a competitive grant from the Medical faculty of the Saarland University (HOMFOR, to I. Bogeski).

\section{References}

[1] E. Carafoli, Calcium signalling: a tale for all seasons, Proc. Natl. Acad. Sci. U.S.A. 99 (2002) 1115-1122.

[2] A. Quintana, D. Griesemer, E.C. Schwarz, M. Hoth, Calcium dependent activation of T-lymphocytes, Pflugers Arch. 450 (2005) 1-12.

[3] A.B. Parekh, J.W. Putney, Store-operated calcium channels, Physiol. Rev. 85 (2005) 757-810.

[4] G. Grynkiewicz, M. Poenie, R.Y. Tsien, A new generation of $\mathrm{Ca}^{2+}$ indicators with greatly improved fluorescence properties, J. Biol. Chem. 260 (1985) 3440-3450.

[5] W. Droge, Free radicals in the physiological control of cell function, Physiol. Rev. 82 (2002) 47-95.

[6] I. Bogeski, M. Bozem, L. Sternfeld, H.W. Hofer, I. Schulz, Inhibition of protein tyrosine phosphatase $1 \mathrm{~B}$ by reactive oxygen species leads to maintenance of $\mathrm{Ca}^{2+}$ influx following store depletion in HEK 293 cells, Cell Calcium 40 (2006) 1-10.

[7] P.S. Brookes, Y. Yoon, J.L. Robotham, M.W. Anders, S.S. Sheu, Calcium, ATP, and ROS: a mitochondrial love-hate triangle, Am. J. Physiol. Cell Physiol. 287 (2004) C817-C833.

[8] L.S. Terada, Specificity in reactive oxidant signalling: think globally, act locally, J. Cell. Biol. 174 (2006) 615-623.

[9] F. Scholz, U. Schroeder, R. Gulaboski, Electrochemistry of Immobilized Particles and Droplets, Springer, Heidelberg, Berlin, 2005.

[10] F. Scholz, R. Gulaboski, Determining the Gibbs energy of ion transfer across water-organic liquid interfaces with three-phase electrodes, ChemPhysChem. 6 (2005) 16-28.

[11] F. Quentel, V. Mirčeski, M. L'Her, Kinetics of anion transfer across the liquid/liquid interface of a thin organic film modified electrode, studied by means of square-wave voltammetry, Anal. Chem. 77 (2005) 1940-1949.

[12] T.D. Chung, F.C. Anson, Electrochemical monitoring of proton transfer across liquid/liquid interfaces on the surface of graphite electrodes, Anal. Chem. 73 (2001) 337-342.

[13] C.N. Shi, F.C. Anson, Simple electrochemical procedure for measuring the rates of electron transfer across liquid/liquid interfaces formed by coating graphite electrodes with thin layers of nitrobenzene, J. Phys. Chem. B 102 (1998) 9850-9854.

[14] R. Gulaboski, V. Mirčeski, C.M. Pereira, M.N.D.S. Cordeiro, A.F. Silva, F. Quentel, M. L'Her, M. Lovrić, A comparative study of the anion transfer kinetics across a water/nitrobenzene interface by means of electrochemical impedance spectroscopy and square-wave voltammetry at thin organic film-modified electrodes, Langmuir 22 (2006) 3404-3412.

[15] V. Mirčeski, F. Quentel, M. L'Her, F. Scholz, Studying the coupled electron-ion transfer reaction at thin-film modified electrode by means 
of square-wave voltammetry, J. Electroanal. Chem. 586 (2006) 8697.

[16] V. Mirčeski, F. Quentel, M. L'Her, A. Pondaven, Studying the kinetics of the ion transfer across the liquid/liquid interface by means of thin-film modified electrodes, Electrochem. Commun. 7 (2005) 1122-1128.

[17] A.G. Volkov, Liquid Interfaces in Chemical, Biological and Pharmaceutical Applications, Marcel Dekker, New York, 2001.

[18] B. Testa, H. van den Waterbeemd, G. Folkers, R. Guy, Pharmacokinetic Optimization in Drug Research: Biological, Physicochemical and Computational Strategies, Wiley-VCH, Weinheim, 2001.

[19] M. Jorge, R. Gulaboski, C.M. Pereira, M.N.D.S. Cordeiro, Molecular dynamics study of 2-nitrophenyloctyl ether and nitrobenzene, J. Phys. Chem. B 110 (2006) 12530-12538.

[20] R. Gulaboski, A. Galland, G. Bouchard, K. Caban, A. Kretschmer, P.A. Carrupt, Z. Stojek, H.H. Girault, F. Scholz, A comparison of the solvation properties of 2-nitrophenyloctyl ether, nitrobenzene, and $n$ octanol as assessed by ion transfer experiments, J. Phys. Chem. B 108 (2004) 4565-4572.

[21] S. Wilke, Zum Ionentransfer an der Grenzflaeche wenig misbarer Elektrolytloesungen und dessen analytischer Anwendung, Habilitation Thesis, Halle (2002), available on: http://sundoc.bibliothek.unihalle.de/habil-online/02/03H028/habil.pdf.

[22] F. Scholz, Š. Komorsky-Lovric, M. Lovric, A new access to Gibbs energies of transfer of ions across liquid/liquid interface and a new method to study electrochemical processes at well-defined three-phase junction, Electrochem. Commun. 2 (2000) 112-118.

[23] F. Marken, R.G. Compton, C.H. Goeting, J.S. Foord, S.D. Bull, S.G. Davies, Sonoelectrochemistry enhanced electrocatalytic processes: the $\mathrm{Pb}(\mathrm{IV})$ catalyzed cleavage of 1,2-cic-cyclopentanediol at graphite and glassy carbon electrode, Electroanalysis 10 (1998) 821-826.

[24] J.C. Ball, F. Marken, Q. Fulian, J. Wadhawan, A.N. Blythe, U. Schroeder, R.G. Compton, S.D. Bull, S.G. Davies, Voltammetry of electroactive redox droplets. Part II. Comparison of experimental and simulation data for coupled ion and electron insertion processes and evidence for microscale convection, Electroanalysis 12 (2000) 1017-1025.

[25] U. Schoreder, J. Wadhawan, G.R. Evans, R.G. Compton, B. Wood, D.J. Walton, R.R. France, F. Marken, P.C. Bulman Page, C.M. Hayman, Probing thermodynamic aspects of electrochemically driven iontransfer processes across liquid/liquid interfaces: pure versus diluted redox liquids, J. Phys. Chem. B 106 (2002) 8697-8704.

[26] C.E. Banks, T.J. Davies, R.G. Evans, G. Hignett, A. Wain, N.S. Lawrence, J.D. Wadhawan, F. Marken, R.G. Compton, Electrochemistry of immobilized redox droplets: concepts and applications, Phys. Chem. Chem. Phys. 5 (2003) 4053-4069.

[27] V. Mirčeski, R. Gulaboski, F. Scholz, Determination of the standard Gibbs energies of transfer of cations across nitrobenzene/water interface utilizing the reduction of iodine in an immobilized droplet, Electrochem. Commun. 4 (2002) 813-819.

[28] R. Gulaboski, V. Mirčeski, M. Lovric, I. Bogeski, Theoretical study of a surface electrode reaction preceded by a homogeneous chemical reaction under conditions of square-wave voltammetry, Electrochem. Commun. 7 (2005) 515-522.

[29] R.Y. Tsien, T. Pozzan, T.J. Rink, Calcium homeostasis in intact lymphocytes-cytoplasmic free calcium monitored with a new, intracellularly trapped fluorescent indicator, J. Cell Biol. 94 (1982) 325-334.

[30] R.Y. Tsien, T. Pozzan, T.J. Rink, Measuring and manipulating cytosolic $\mathrm{Ca}^{2+}$ with trapped indicators, Trends Biochem. Sci. 9 (1984) 263-266.

[31] I. Maruyama, H. Oyamada, T. Hasegawa, K. Ohtsuka, M. Kobayashi, K. Momose, Loading of Fura-2AM with an aid of DFP single smoothmuscle cells prepared from guinea-pig taenia-coli, J. Pharmacol. Methods 21 (1989) 1-12.

[32] A.P. Jackson, M.P. Timmerman, C.R. Bagshaw, C.C. Ashley, The kinetics of calcium binding to Fura-2 and Indo-1, FEBS Lett. 216 (1987) $35-39$.

[33] A. Verkhratsky, E.C. Toescu, Integrative aspects of Calcium Signalling, Plenum Press, New York, 1998. 